\title{
Altered Processing of Pro-Orphanin FQ/Nociceptin and Pro- Opiomelanocortin-Derived Peptides in the Brains of Mice Expressing Defective Prohormone Convertase 2
}

\author{
Richard G. Allen, ${ }^{2}$ Bonnie Peng, ${ }^{1}$ Michael J. Pellegrino, ${ }^{2}$ Emilie D. Miller, ${ }^{3}$ David K. Grandy, ${ }^{4}$ \\ James R. Lundblad, ${ }^{5}$ Carrie L. Washburn, ${ }^{2}$ and John E. Pintar ${ }^{1}$ \\ ${ }^{1}$ Neuroscience and Cell Biology, University of Medicine and Dentistry of New Jersey-Robert Wood Johnson Medical \\ School, Piscataway, New Jersey 08854, and ${ }^{2}$ Center for Research on Occupational and Environmental Toxicology, \\ ${ }^{3}$ Neuroscience Graduate Program, and Departments of ${ }^{4}$ Physiology and Pharmacology and 5 Molecular Medicine, Oregon \\ Health Sciences University, Portland, Oregon 97201
}

\begin{abstract}
The bioactivity of neuropeptides can be regulated by a variety of post-translational modifications, including proteolytic processing. Here, gene-targeted mice producing defective prohormone convertase 2 (PC2) were used to examine the posttranslational processing of two neuroendocrine prohormones, pro-opiomelanocortin (POMC) and pro-orphanin FQ (pOFQ)/ nociceptin (N), in the brain. Reversed-phase HPLC and gelexclusion chromatography were combined with specific radioimmunoassays to analyze the processing patterns of these two prohormones in the hypothalamus and the amygdala. In the case of POMC, the lack of PC2 activity completely prevented carboxy-shortening of $\beta$-endorphins and greatly diminished conversion of $\beta$-lipotropin to $\gamma$-lipotropin and $\beta$-endorphin. Al-
\end{abstract}

though conversion of $\beta$-lipotropin to $\beta$-endorphin decreased, the lack of PC2 activity caused an increase in $\beta$-lipotropin and $\beta$-endorphin levels in the mutant animals, but no increases in $\mathrm{POMC}$ or biosynthetic intermediates were seen. The extent of OFQ/N production was significantly lower in PC2-deficient mice and there was an accumulation of relatively large amounts of $\mathrm{pOFQ} / \mathrm{N}$ and biosynthetic intermediates. These results demonstrate that PC2 is directly involved in the biogenesis of two brain neuropeptides in vivo and suggest that the specific prohormone and cellular context influences neuropeptide processing by PCs.

Key words: neuropeptide; proteolytic processing; proorphanin FQ/nociceptin; POMC; PC2; gene-targeting
Neuropeptides are generated from inactive precursors by proteolytic processing and concentrated into large, dense core vesicles for release (Sossin et al., 1989). Two members of the subtilisinlike prohormone convertase (PC) family, PC2 and PC1/PC3 (PC1), play major roles in neuroendocrine precursor processing and appear to provide the basis for the tissue-specific aspects of proteolytic peptide processing (Rouille et al., 1995). PC1 and PC2 are expressed exclusively in the brain and neuroendocrine systems, whereas other members of this family are expressed more ubiquitously (Rouille et al., 1995; Zhou et al., 1999).

Over the last two decades, the tissue-specific, proteolytic processing of the neuroendocrine prohormone pro-opiomelanocortin (POMC) has been studied in great detail, particularly in the pituitary gland, and has been found to be correlated with PC expression (Mains et al., 1977; Eipper and Mains, 1980; Mains and Eipper, 1981; Rouille et al., 1995). These studies have shown that PC1 is expressed at high levels in the anterior lobe of the pituitary gland, whereas both PC2 and PC1 are expressed in the intermediate lobe (Day et al., 1992; Seidah and Chretien, 1992). PC2 is believed to be responsible for the additional cleavages of POMC-

\footnotetext{
Received Jan. 10, 2001; revised May 9, 2001; accepted May 22, 2001.

This work was supported in part by National Institutes of Health Grants DA11282 (R.G.A.), DA08562 and DA10703 (D.K.G.), and DA08622 (J.E.P.). We thank D. F. Steiner and the University of Chicago Diabetes Research and Training Center for providing the PC2 null mouse strain. We also thank Dan Austin and Harlene Finn.

Correspondence should be addressed to Dr. Richard G. Allen, Oregon Health Sciences University, The Center for Research on Occupational and Environmental Toxicology, 3181 Southwest Sam Jackson Park Road, L606, Portland, OR 97201. E-mail: allenr@ohsu.edu.

Copyright (C) 2001 Society for Neuroscience $\quad 0270-6474 / 01 / 215864-07 \$ 15.00 / 0$
}

derived peptides found in the intermediate pituitary (Rouille et al., 1995). POMC processing has also been studied in the rat hypothalamus, and the extent of proteolytic processing is similar to the POMC peptide processing patterns found in the neurointermediate pituitary (Emeson and Eipper, 1986). The hallmarks of this proteolytic processing are the essentially complete conversion of $\beta$-lipotropin ( $\beta$-LPH) to $\gamma$-LPH and $\beta$-endorphin and the subsequent carboxy-shortening of approximately one-third of the $\beta$-endorphin 1-31 molecules to $\beta$-endorphin 1-27 and 1-26. Figure $1 A$ summarizes the general proteolytic processing patterns of the $\beta$-LPH- $\beta$-endorphin domain in the rat hypothalamus.

Prepro-orphanin FQ (ppOFQ)/nociceptin (N) is a prohormone encoding the neuropeptide $\mathrm{OFQ} / \mathrm{N}$, as well as other potential peptides (Bunzow et al., 1994; Meunier et al., 1995; Reinscheid et al., 1995). OFQ/N and its receptor $\left(\mathrm{ORL}_{1}\right)$ are expressed abundantly in the brain and spinal cord (Houtani et al., 2000) and have been implicated in a variety of physiological processes, such as cell excitability (Vaughan et al., 1997; Yu et al., 1997; Pan et al., 2000) and cAMP production (Reinscheid et al., 1995); they also possess nociceptive and anxiolytic properties (Jenck et al., 1997; Koster et al., 1999). Relatively little is known about pOFQ/N processing or the role of the PCs in the generation of individual neuropeptides from the proprotein, although we have shown previously that the major $\mathrm{OFQ} / \mathrm{N}$-containing peptide produced in the rat, mouse, and monkey hypothalamus is OFQ/N1-17 (Quigley et al., 1998). Figure $1 B$ summarizes what is known about $\mathrm{pOFQ} / \mathrm{N}$ proteolytic processing.

Mice lacking an active PC2 exhibit defective hormone processing in the proinsulin, proglucagon, and prosomatostatin systems 

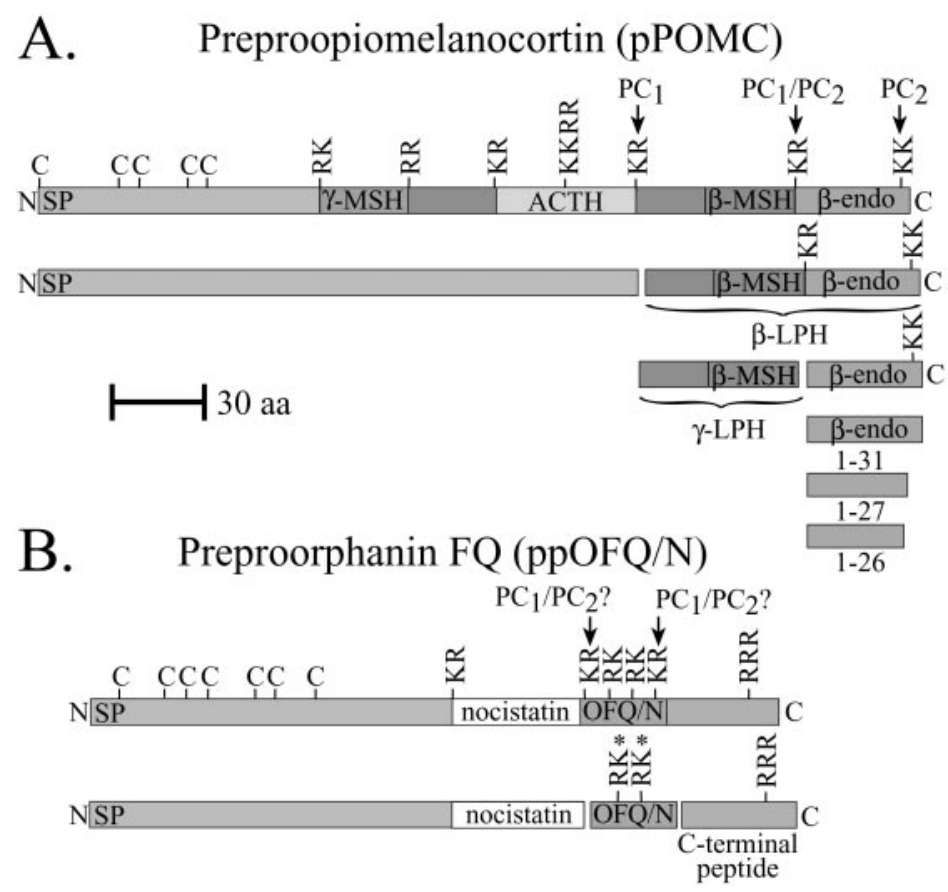

Figure 1. A, C-terminal proteolytic processing of pre-POMC ( $p P O M C)$. A schematic representation of the $\beta$ - $\mathrm{LPH}-\beta$-endorphin processing pathway in the rodent hypothalamus. $B$, A schematic representation of ppOFQ/N processing in the rodent hypothalamus. Predicted and potential cleavages by PCland PC2 based on pituitary POMC processing are indicated. The processing patterns shown are thought to occur in mice expressing WT PC2. $K$, Lysine; $R$, arginine. Asterisks denote potential paired basic cleavages in OFQ/N. Arrows denote PC cleavage sites.

of the pancreas (Furuta et al., 1997). In the present study, we have used these mice to examine the effects of PC2 deficiency on the processing of two neuroendocrine precursors in specific brain tissues (Fig. 1). Here we use radioimmunoassays (RIAs) for POMC-derived peptides $[\beta$-endorphin and $\beta$-melanocytestimulating hormone $(\beta-\mathrm{MSH})]$ and for $\mathrm{OFQ} / \mathrm{N}$, combined with biochemical fractionation methods, to show that lack of a functional $\mathrm{PC} 2$ affects both rate and site-specific proteolytic cleavages of $\mathrm{pOFQ} /$ nociceptin and POMC-derived peptides in a proprotein-specific manner.

\section{MATERIALS AND METHODS}

Animals. All $+/+$ and PC2-deficient $-/-$ mice bred were littermates obtained from the mating of PC2 $+/-$ mice initially provided by Dr. D. Steiner (Howard Hughes Medical Institute, University of Chicago, Chicago, IL). The PC2-deficient mice contain an insertion of a neomycin cassette into exon 3 of the PC2 gene (Furuta et al., 1997). This insertion alters transcript splicing and prevents activation of the mutated PC2 precursor. Homozygous $-/-$ mice thus lack any PC 2 activity. All animals were housed and used according to institutional guidelines prescribed by the National Institutes of Health.

Tissue isolation and sample preparation. Individual hypothalamic and amygdala tissues from wild-type (WT), heterozygous, and homozygous mutant mice were extracted in $0.5 \mathrm{ml}$ of $10 \%$ acetic acid containing 0.5 $\mathrm{mg} / \mathrm{ml}$ bovine serum albumin (BSA) and protease inhibitors $(1 \mu \mathrm{l} / \mathrm{ml}$ protease inhibitor cocktail; Sigma, St. Louis, MO). Samples were homogenized manually and then frozen and thawed three times. Tissue extracts were centrifuged, and the supernatants were lyophilized for peptide analyses.

Reversed-phase HPLC. After lyophilization, tissue extracts were resuspended in $500 \mu \mathrm{l}$ of trifluoroacetic acid (TFA) and injected onto a Vydac (214TP54) RP-HPLC column (C4, $300 \AA$ pore size; The Separations Group, Hesperia, CA). The extracts were fractionated using a Waters (Milford, NJ) reversed phase (RP)-HPLC system with linear gradients of acetonitrile in $0.1 \%$ TFA and a flow rate of $1 \mathrm{ml} / \mathrm{min}$. Generally, $801-\mathrm{min}$ fractions were collected using a gradient of $8-36 \%$ acetonitrile. An additional gradient starting with $13.6 \%$ acetonitrile for $3 \mathrm{~min}$, a step-up to $17.6 \%$ acetonitrile in $2 \mathrm{~min}$, and then a linear gradient to $36 \%$ acetonitrile at $80 \mathrm{~min}$ was used for some POMC peptide fractionations Aliquots were then vacuum dried before RIA. In some cases, an additional isocratic elution at $36 \%$ acetonitrile, after the linear gradient, was used to elute POMC.

Gel-exclusion chromatography. Lyophilized extracts were resuspended in $0.5 \mathrm{ml}$ of $3 \mathrm{M}$ acetic acid and injected onto a $1 \times 35 \mathrm{~cm}$ column (Bio-Rad, Richmond, CA) of Sephadex G-50 (Pharmacia, Piscataway, NJ) using $3 \mathrm{~m}$ acetic acid containing $10 \mu \mathrm{g} / \mathrm{mg}$ BSA to elute the peptides by FPLC (Pharmacia). The flow rate was $1 \mathrm{ml} / \mathrm{min}$, and $1 \mathrm{~min}$ fractions were collected. Molecular weight markers are shown in the figures.

$R I A$. The $\mathrm{OFQ} / \mathrm{N}$ antiserum is specific to the $\mathrm{C}$ terminus of $\mathrm{OFQ} /$ N1-17 and does not cross-react with $\beta$-endorphin or dynorphin (DYN) A. Tyr14 OFQ/nociceptin was iodinated using the chloramine-T method (Quigley et al., 1998). The $\beta$-endorphin and $\beta$-MSH RIAs have been described previously (Hatfield et al., 1988). The $\beta$-endorphin antiserum is specific to the mid-portion of $\beta$-endorphin $1-31$ and cross-reacts $1: 1$ with all $\beta$-endorphins and $\beta$-LPH (Hatfield et al., 1988). The $\beta$-MSH antiserum is specific to the mid-portion of $\beta$-MSH and cross-reacts with the $\mathrm{C}$ terminus of $\gamma$-LPH (Hatfield et al., 1988; Thorne and Thomas, 1990). An antiserum specific for mouse (m)ppOFQ/N160-187 was generated in rabbits against the synthesized peptide after conjugation by Covance (Denver, PA). This antiserum (VO61) was used at a final dilution of 1:3000 and does not cross-react with $\mathrm{OFQ} / \mathrm{N}, \mathrm{mppOFQ} /$ N160-176, or dynorphin A1-13. It also shows minimal cross-reactivity with mppOFQ/N181-187. Thus, the potential internal RRR cleavage site in pOFQ/N160-187 must be intact for full reactivity (Mathis et al., 2001). Vacuum-dried samples were resuspended in phosphate buffer containing $\beta$-mercaptoethanol and BSA for RIA. All of the RIA procedures were performed as described previously (Quigley et al., 1998). The RIAs have a sensitivity of $\sim 1.8 \times 10^{-3} \mathrm{pmol} /$ tube. Recovery of input immunoreactivity of single or pooled brain tissues was $\sim 85-90 \%$. All peptide nomenclature is based on the mouse primary amino acid sequences of $\mathrm{pOFQ} / \mathrm{N}$ and POMC.

\section{RESULTS}

\section{Lack of a functional PC2 decreases $\beta$-LPH conversion to $\gamma$-LPH and $\beta$-endorphin and abolishes carboxy- shortening of $\beta$-endorphin 1-31 in vivo}

We fractionated WT and mutant hypothalamic extracts by RPHPLC and assayed the fractions for $\beta$-endorphin and $\beta$-MSH immunoreactivity. In the WT hypothalamus, almost all of the $\beta$-MSH immunoreactivity is present as $\gamma$-LPH (Fig. $2 A$ ). However, in the PC2-deficient mice, only approximately one-third of the $\beta$-LPH was converted to $\gamma$-LPH and $\beta$-endorphin. This result suggests that $\mathrm{PC} 2$ is required to complete the in vivo conversion of $\beta$-LPH to $\gamma$-LPH and $\beta$-endorphin $1-31$. Figure $2 B$ confirms that the major peak of immunoreactive material at $76 \mathrm{~min}$ is $\beta$-LPH, as demonstrated by a single, large peak containing essentially equal amounts of $\beta$-endorphin and $\beta$-MSH immunoreactivity. An additional peak of $\beta$-MSH immunoreactivity at $43 \mathrm{~min}$ in the WT animals is absent in the mutants. This peptide is a $\mathrm{C}$-terminal fragment of $\gamma$-LPH derived from a cleavage at leu10glu11 of $\gamma$-LPH (Thorne and Thomas, 1990).

We subsequently determined the relative sizes of the $\beta$-endorphin-immunoreactive material by gel-exclusion chromatography of WT and PC2-deficient hypothalamic extracts. Figure 3 shows that essentially all of the $\beta$-LPH has been converted to $\beta$-endorphin-sized material in the WT hypothalamus, as was found in the RP-HPLC analyses, whereas in the PC2-deficient animals, only approximately one-third of the $\beta$-LPH was converted to $\beta$-endorphin. The inset in Figure 3 shows that only $\sim 34 \%$ of $\beta$-LPH was cleaved to $\beta$-endorphin, whereas in the WT animals, $\sim 96 \%$ of the $\beta$-LPH was converted to $\beta$-endorphinsized material. 


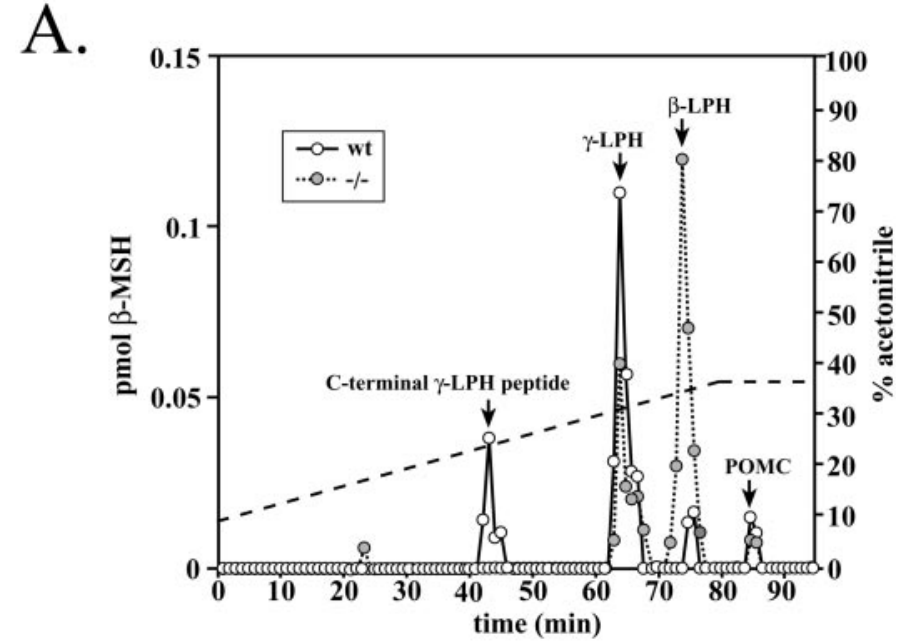

B.

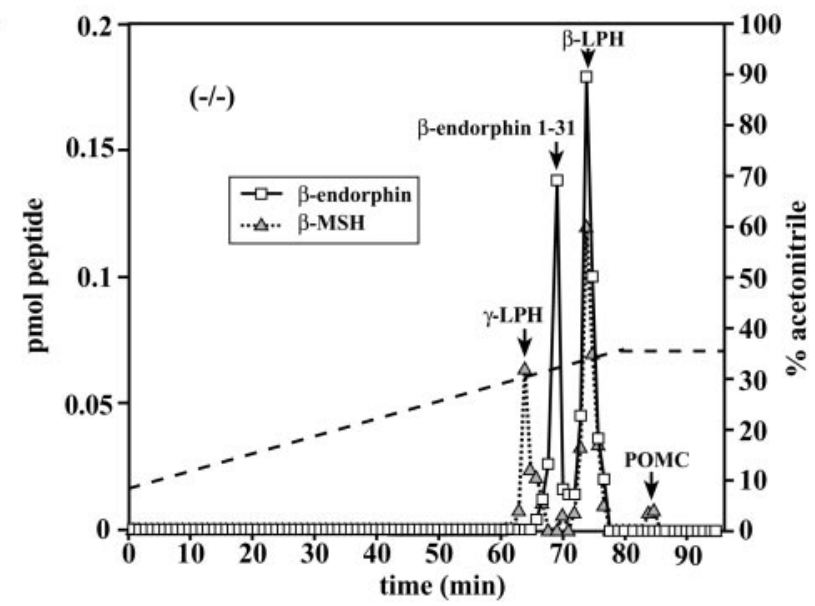

Figure 2. $\beta$ - $\mathrm{LPH}$ domain processing in $\mathrm{WT}$ and $\mathrm{PC} 2$ mutant mouse hypothalamic extracts. RP-HPLC fractions were assayed for $\beta$-endorphin and $\beta$-MSH immunoreactivity. The dashed line indicates the acetonitrile gradient. $A$, WT $\beta$-MSH and mutant animals. $B$, Mutant PC2. Results shown are representative of four separate determinations.

PC2 has been proposed to convert $\beta$-endorphin $1-31$ to its carboxy-shortened form, $\beta$-endorphin 1-27 (Zhou and Mains, 1994). To determine whether mouse hypothalamic $\beta$-endorphin 1-31 is carboxy-shortened, we fractionated extracts by gel filtration as in Figure 3, pooled the $\beta$-endorphin-sized material, and fractionated the pooled fractions using a gradient that was slightly different from that shown in Figure 2. Figure $4 A$ shows that in the WT hypothalamus, some of the $\beta$-endorphin $1-31(\sim 40 \%)$ has been converted to $\beta$-endorphin 1-27 and 1-26. Figure $4 B$ shows that the $\beta$-endorphin 1-31 was not processed to carboxyshortened peptides to any appreciable extent in the mutant hypothalamus. The small amount of immunoreactive material eluting at $62-64 \mathrm{~min}$ is $\beta$-LPH carryover from the pooled fractions.

\section{Lack of a functional PC2 causes incomplete conversion of $\mathrm{POFQ} / \mathrm{N}$ to $\mathrm{OFQ} / \mathrm{N}$ in vivo}

We then examined the extent of ppOFQ/N processing in PC2deficient mice using an antibody to OFQ (1-17) that can recognize biosynthetic intermediates (BSIs), as well as the proprotein. Figure $5 A$ shows that in the WT hypothalamus virtually all of the $\mathrm{OFQ} / \mathrm{N}$ immunoreactivity elutes at $31 \mathrm{~min}$. In contrast, Figure $5 B$

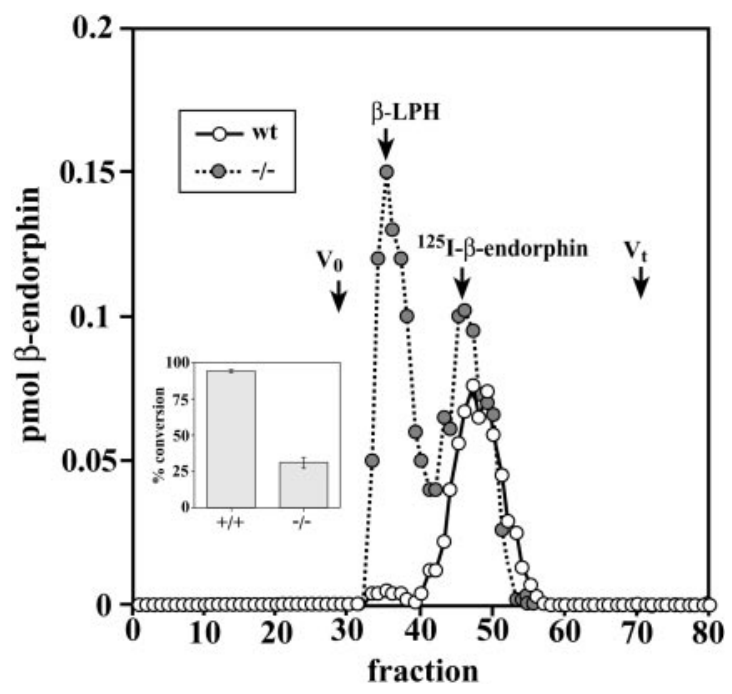

Figure 3. Sephadex G-50 gel-exclusion chromatography of WT and mutant PC2 hypothalamic extracts. The fractions were assayed for $\beta$-endorphin immunoreactivity. The arrow indicates the elution position of ${ }^{125} \mathrm{I}$-acetyl- $\beta$-endorphin $1-27$. $V_{0}$, Exclusion volume; $V_{t}$, total column volume. The inset shows the percentage of conversion of $\beta$-LPH to $\beta$-endorphin in a WT compared with a PC2 mutant mouse hypothalamus. The percentage of conversion is the ratio of the immunoreactivity eluting $3-3.5 \mathrm{kDa} \beta$-endorphin to the total $\beta$-endorphin immunoreactivity. Several RP-HPLC analyses were used for this calculation. $n=3 ; p=0.0063$; unpaired $t$ test using StatView (Abacus Concepts, Calabasas, CA).

shows that although some $\mathrm{OFQ} / \mathrm{N}$ is produced and elutes at 30-31 min, relatively large amounts of a pOFQ/N-like molecule elute at $70 \mathrm{~min}$. Potential BSIs containing the OFQ/N epitope (66-67 $\mathrm{min})$ were also detected in hypothalamic extracts obtained from PC2 mutant mice. Figure $5 C$ shows that proteolytic processing in the heterozygote is very similar to the processing observed in the WT, indicating that one-half of the PC2 enzymatic activity expressed in the heterozygotes is sufficient to produce WT proteolytic-processing patterns. We also noted a reduction in the total amount of $\mathrm{OFQ} / \mathrm{N}$-immunoreactive material contained in extracts from PC2 mutant animals. These results indicate that $\mathrm{PC} 2$ is required for complete processing of the OFQ/N precursor and OFQ/N-containing intermediates; its absence causes a substantial reduction in $\mathrm{OFQ} / \mathrm{N}$ immunoreactivity.

To more fully characterize the effects on OFQ/N processing, we fractionated hypothalamic extracts by gel-exclusion chromatography. The open circles in Figure 6 indicate that virtually all of the OFQ/N immunoreactivity co-elutes with ${ }^{125} \mathrm{I}-\mathrm{OFQ} / \mathrm{N}$ in WT animals, whereas larger relative amounts of $\mathrm{pOFQ} / \mathrm{N}$-sized material were detected in the PC2 mutant animals. As with the HPLC fractionations, much smaller amounts of OFQ/N immunoreactivity relative to the proprotein were detected in the PC2defective animals. The inset in Figure 6 shows that using the HPLC fractionations, only $\sim 30 \%$ of the total immunoreactivity is converted to OFQ/N in the mutants, compared with $\sim 98 \%$ in the WT animals. The total amount of OFQ/N immunoreactivity found in the HPLC fractionations from mutant mice ranged from 10 to $40 \%$ of WT values.

We also examined proteolytic processing of $\mathrm{OFQ} / \mathrm{N}$ in the amygdala. In the WT amygdala, virtually all of the immunoreactive OFQ/N eluted at 31-32 min (Fig. 7), similar to our previous findings analyzing hypothalamic extracts. In the PC2-deficient mice, the peak of OFQ/nociceptin was greatly reduced, and new 
A.

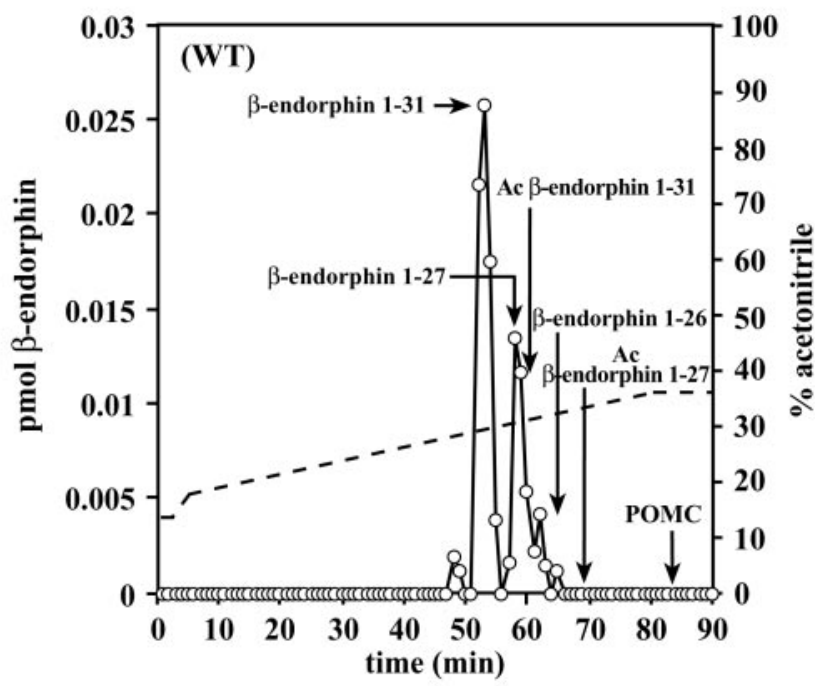

B.

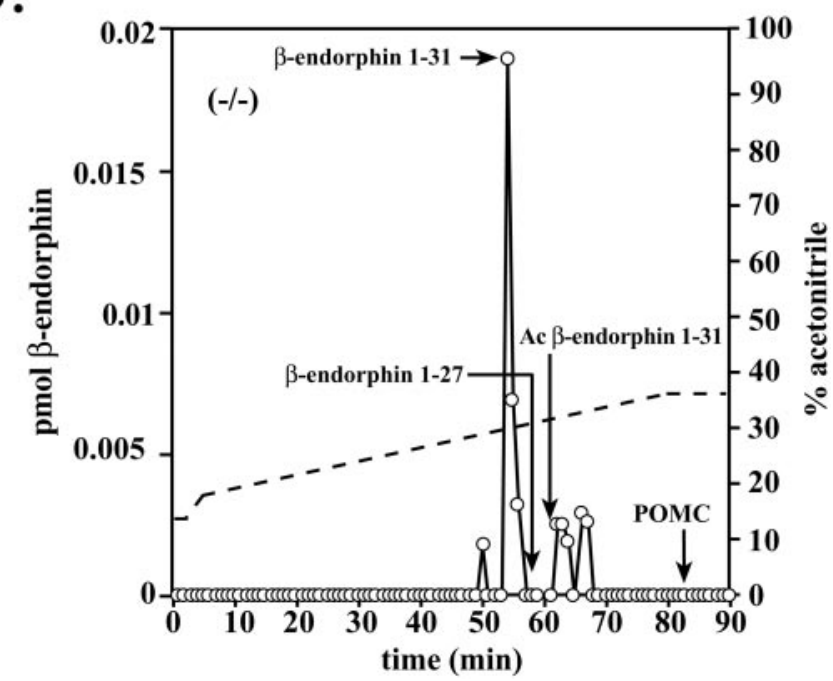

Figure 4. RP-HPLC fractionation of WT and PC2-deficient mouse hypothalamic extracts after gel exclusion, as in Figure 3. The pooled extracts of $\beta$-endorphin-sized material were fractionated on the gradient indicated, and the fractions were assayed for $\beta$-endorphin immunoreactivity. The arrows indicate the elution times of authentic $\beta$-endorphin peptides. The dashed line indicates the acetonitrile gradient. Similar results were seen in two experiments. $A c$, Acetyl.

peaks of immunoreactivity were detected at $71 \mathrm{~min}(\mathrm{pOFQ} / \mathrm{N})$ and 66-67 min (Fig. 7, filled circles). Thus, in both the amygdala and the hypothalamus of the PC2 mutants, small amounts of OFQ/N were produced; however, processing does not proceed to completion, because unprocessed and partially processed immunoreactive material containing the $\mathrm{OFQ} / \mathrm{N}$ epitope were detected. We also found that in the amygdala, as in the hypothalamus, the level of mature OFQ/N immunoreactivity was dramatically reduced in the mutants. This result again supports the notion that $\mathrm{PC} 2$ is required for complete conversion of $\mathrm{pOFQ} / \mathrm{N}$ to the 17 amino acid OFQ/N peptide in the brain.

In addition, we assayed the HPLC fractions using an RIA directed against the $\mathrm{C}$ terminus of the $\mathrm{OFQ} / \mathrm{N}$ proprotein (Mathis et al., 2001). In the WT and heterozygote hypothalamus, we found two major peaks of C-terminus immunoreactivity eluting at 62 and $66 \mathrm{~min}$, with synthetic C-terminal peptide eluting at 62 min (Fig. 8A). As shown previously, OFQ/N elutes at $31 \mathrm{~min}$ (Fig. $5 A$ ). In the mutant animals, the major peak of both OFQ/N and C-terminal immunoreactivity eluted at $71 \mathrm{~min}$, and the relative amounts of immunoreactivity eluting at 62 and $66 \mathrm{~min}$ decreased markedly (Fig. $8 B$ ). These results support the notion that a moiety eluting at $71 \mathrm{~min}$ contains both the $\mathrm{C}$-terminal and $\mathrm{OFQ} / \mathrm{N}$ epitope and is most likely pOFQ/N. The peaks eluting at 62 and 66 min appear to be the full-length $\mathrm{C}$-terminal peptide and a derivative containing an intact internal RRR sequence.

\section{DISCUSSION}

The proteolytic processing patterns of POMC-derived peptides have been studied previously in the rat hypothalamus (Emeson and Eipper, 1986). Those studies demonstrated that POMC processing in the hypothalamus resembled the processing pattern in the neurointermediate pituitary rather than the anterior pituitary (Eipper and Mains, 1981; Emeson and Eipper, 1986). The exception to this was the lack of acetylation needed to produce $\alpha-N$ acetylated endorphins and MSH. Thus, in the rat, almost all of the hypothalamic $\beta$-LPH was converted to $\beta$-endorphin $1-31$ related molecules, and approximately one-third of this population was carboxy-shortened. We found essentially the same result in the WT mouse hypothalamus (Figs. 3, 4).

Zhou and Mains (1994) found that overexpression of PC2 in AtT-20 anterior pituitary cells resulted in enhanced proteolytic cleavages at specific, paired-basic sites. In the case of $\mathrm{PC} 2$, it enhanced the conversion of $\beta$-LPH to $\gamma$-LPH and $\beta$-endorphin and produced carboxy-shortened $\beta$-endorphin 1-27. As predicted, we found no carboxy-shortened $\beta$-endorphins in the hypothalamus of mice lacking a functional PC2; thus, PC1 does not cleave at the $\beta$-endorphin $\mathrm{C}$-terminal $\mathrm{KK}$ site in vivo. We found that lack of a functional PC2 greatly diminished (by two-thirds) the conversion of $\beta$-LPH to $\gamma$-LPH and $\beta$-endorphin in vivo. We did not find any increase in unprocessed POMC in brain tissues from the mutant mice, unlike our studies of pituitary POMC processing in PC2 mutant mice (Allen et al., 1999).

The results obtained by examining $\mathrm{pOFQ} / \mathrm{N}$ processing in specific brain tissues were in contrast to these observations. In both the hypothalamus and the amygdala, we found that lack of a functional PC2 resulted in an increase in unprocessed OFQ/Ncontaining material, including $\mathrm{pOFQ} / \mathrm{N}$. Also, in contrast to the POMC pathway, there was a reduction in the OFQ/ $\mathrm{N}$ immunoreactivity in both the hypothalamus and amygdala of the mutant animals. The decrease in the production of mature OFQ/N suggests that $\mathrm{PC} 2$ is much more active than $\mathrm{PC} 1$ in cleaving the $\mathrm{KR}$ sites bounding OFQ/N (Fig. 1B). The PC2-deficient mice used here have been examined for DYN processing in the brain (Berman et al., 2000). These studies showed a substantial reduction in DYN A8, DYN A17, and DYN B13, and it was concluded that PC2 was critical for DYN peptide production.

The presence of PC2 activity completes the conversion of $\beta$-LPH to $\beta$-endorphin and carboxy-shortens some of the $\beta$-endorphin $1-31$ to $\beta$-endorphin $1-27$ in vitro. PC2 is autoactivated in the acidic environment of a late post-Golgi compartment (Lamango et al., 1999), and it is after early cleavages by PC1 that PC2 performs its functions. Our studies confirm the in vitro studies using POMC pituitary cells as a model; however, in vivo, PC1 (presumably) was able to convert a substantial amount of $\beta$-LPH to $\gamma$-LPH and $\beta$-endorphin, as seen in the mutant animals (Fig. $2 A$ ). In fact, the processing profile resembles the pattern found in the mouse anterior pituitary (Eipper and Mains, 1980). 


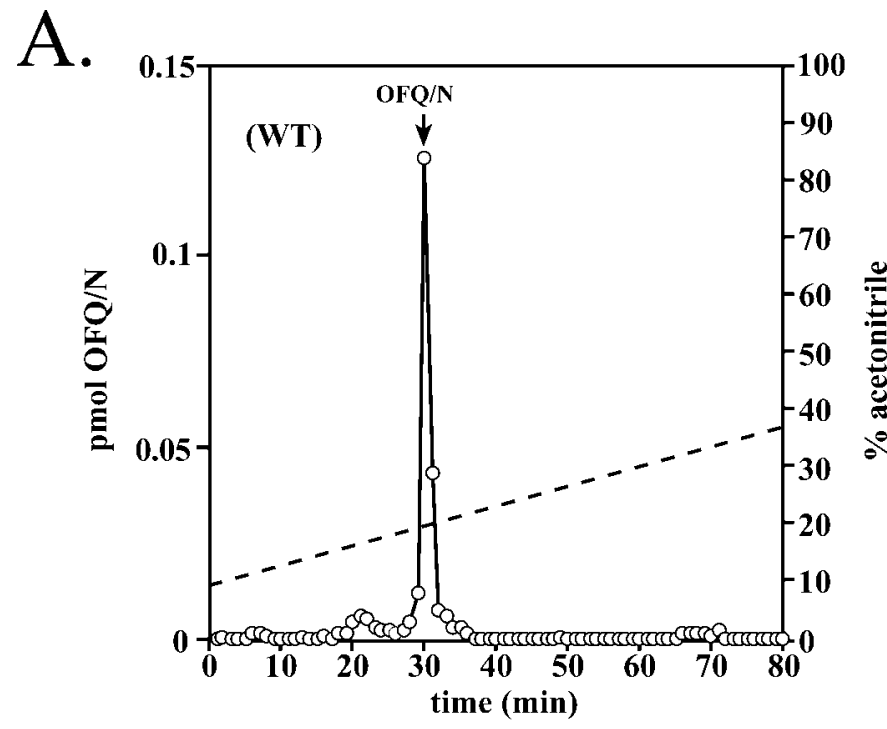

B.

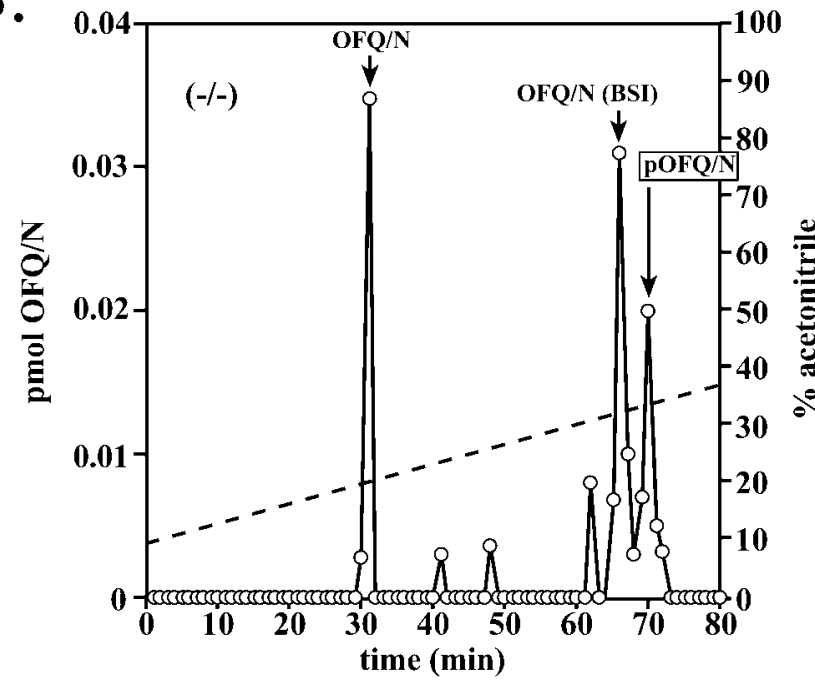

C.

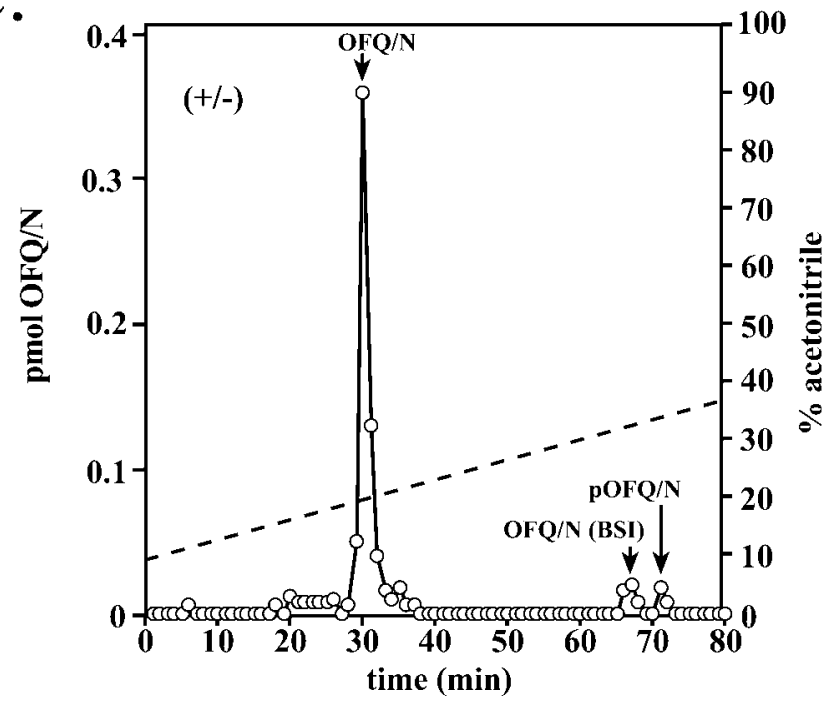

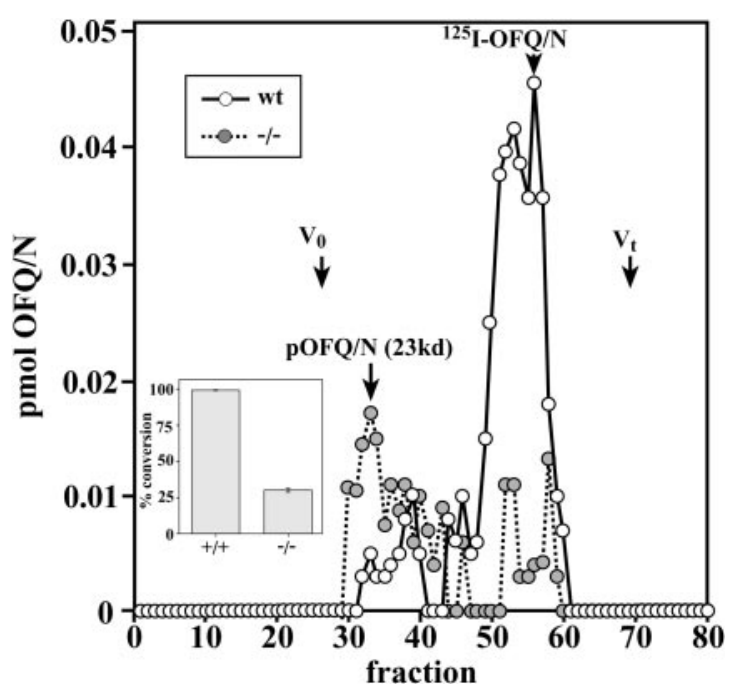

Figure 6. Sephadex G-50 chromatography of WT and PC2 mutant mouse hypothalamic extracts. Gel filtration was performed as described in Materials and Methods. Portions of the fractions were vacuum dried and assayed for OFQ/N immunoreactivity. ${ }^{125} \mathrm{I}-\mathrm{OFQ} / \mathrm{N}$ elutes at fraction 55. Cytochrome $\mathrm{C}$ (molecular mass, $22.5 \mathrm{kDa}$ ) elutes at fraction $33-34 . V_{o}$, Exclusion volume; $V_{t}$, total column volume. Conversion of total OFQ/N immunoreactivity to mature peptide in $\mathrm{WT}$ and $\mathrm{PC} 2$ mutant mouse hypothalamus is shown in the inset. The percentage of conversion is the ratio of the immunoreactivity co-eluting with synthetic OFQ/N at $31 \mathrm{~min}$ to the total OFQ/N immunoreactivity. We used RP-HPLC analyses for this calculation. $n=3 ; p=0.002$; unpaired $t$ test using StatView.

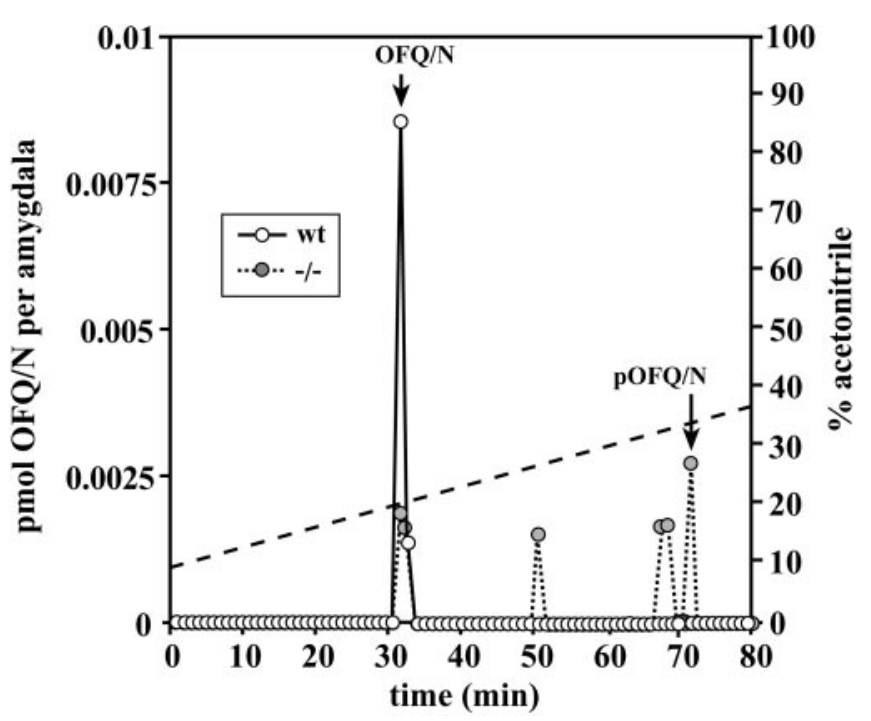

Figure 7. RP-HPLC fractionation of WT and PC2 mutant amygdala extracts. Extracts from WT animals (open circles) and PC2 mutant animals ( filled circles) were fractionated using a linear gradient of $8-36 \%$ acetonitrile (dashed line). The fractions were assayed for $\mathrm{OFQ} / \mathrm{N}$ immunoreactivity. The arrow indicates the elution time of synthetic OFQ/N. The profile shown is representative of four separate determinations.

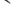

Figure 5. RP-HPLC fractionation of (WT) and PC2 mutant mouse hypothalamic extracts (one mouse hypothalamic equivalent). Extracts from WT $(A)$, PC2-deficient $(B)$, and heterozygous $(C)$ mice were fractionated using a linear gradient of $8-36 \%$ acetonitrile (dashed line). The fractions were assayed for $\mathrm{OFQ} / \mathrm{N}$ immunoreactivity. The arrow indicates the elution position of synthetic OFQ/N. The profile shown is representative of four separate determinations. 


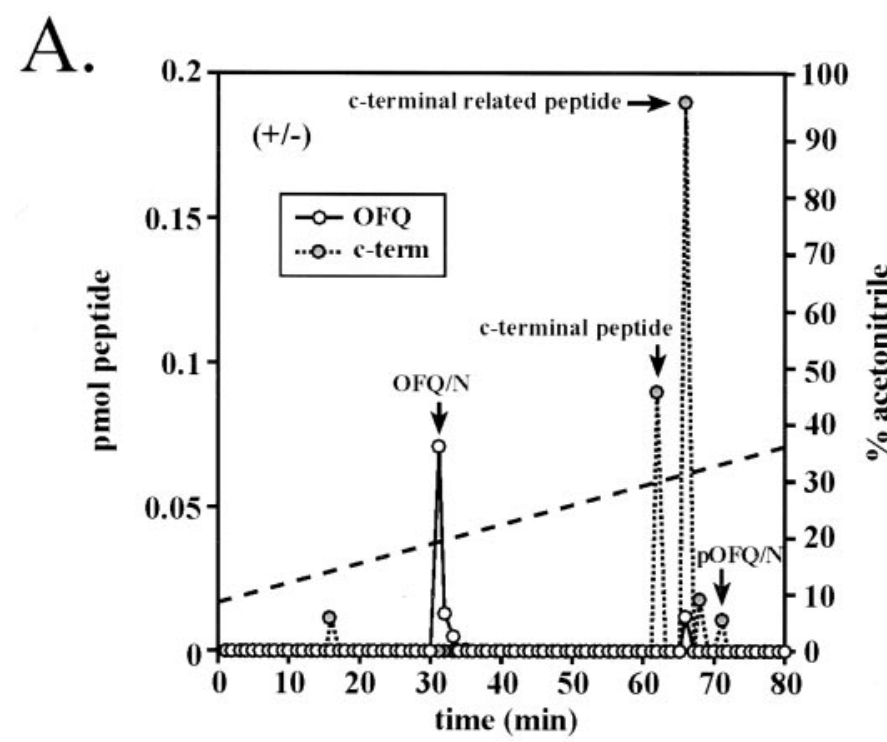

B.

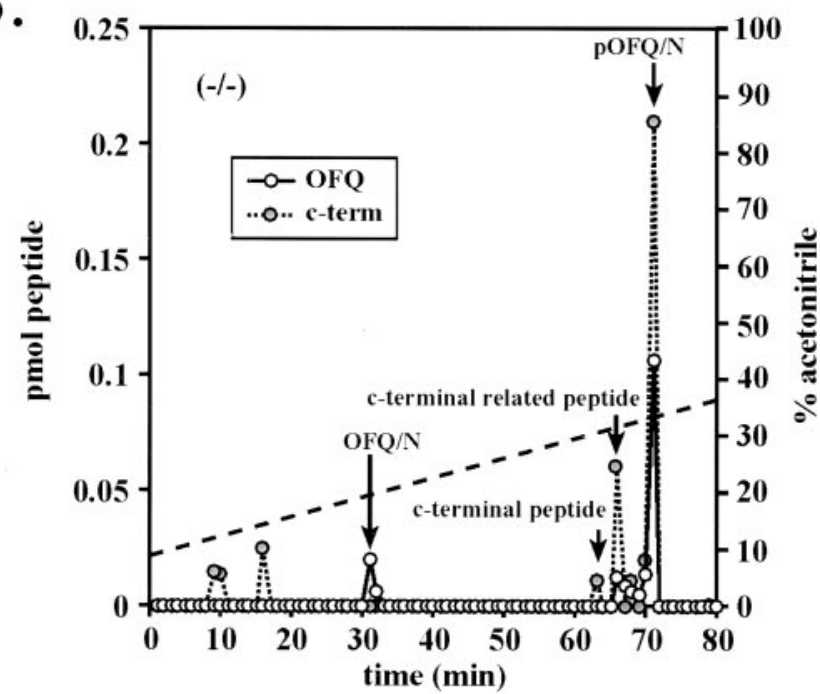

Figure 8. Fractionation of pOFQ/N C-terminal (c-term)-containing peptides in WT and PC-2-deficient mice. Extracts were fractionated as described in Figure 5, and the fractions were assayed for OFQ/N and $\mathrm{C}$-terminal peptide immunoreactivity. The elution positions of synthetic peptides are indicated by the arrows. The dashed line indicates the percentage of acetonitrile. $A$, Heterozygote; $B$, PC null.

This general scenario holds true with regard to some of the pOFQ/N cleavages at KR sites (Fig. 1), but unlike the $\beta$-endorphin immunoreactivity, we found a reduction in $\mathrm{OFQ} / \mathrm{N}$ immunoreactivity in the mutant, as well as relative increases in unprocessed prohormone and a putative biosynthetic intermediate. Thus, the effects of a nonfunctional PC2 on propeptide processing are different, depending on which proprotein pathway is examined. What still remains unclear is what prevents PC1 from completely cleaving at all of the KR sites examined in our studies. There is no sequence homology bounding the KR sites examined here in either $\mathrm{pOFQ} / \mathrm{N}$ or POMC; thus, site-specific amino acid sequence homology does not explain why conversion stops.

Very recently an inhibitor of PC1 called proSAAS has been cloned and characterized (Fricker et al., 2000). The expression of
proSAAS in AtT-20 cells results in a substantial reduction in the rate of endogenous POMC processing. We know that there are activators of $\mathrm{PCs}$, because the $7 \mathrm{~B} 2$ protein is essential for the activation and maturation of PC2 (Lamango et al., 1999). Because there are specific inhibitors and activators for PCs, their existence may provide the answer to the incomplete conversion at specific $\mathrm{KR}$ sites in POMC and pOFQ/N. PC1 and PC2 show temporal and spatial expression during development (Marcinkiewicz et al., 1993; Zheng et al., 1994); thus, it will also be interesting to examine the effects of PC2 deficiency on pOFQ/N and POMC processing during fetal development.

We have shown that the lack of functional PC2 produces aberrant processing in two neuroendocrine prohormone pathways. Not only is PC2 required for site-specific cleavages, but it also appears to play a role in the conversion of certain intermediates in vivo. In the case of pOFQ/N, PC2 appears to affect the amount of end product peptide produced. We have also shown that expression of a nonfunctional PC2 can affect processing in a prohormone-specific manner. The ability to generate multiple biological activities from a given prohormone is an efficient way to create physiological diversity without the use of gene products encoding each peptide separately. It has been shown previously that PC1 and PC2 can be regulated by a variety of modulators, such as neurotransmitters, steroid hormones, and hypothalamic releasing factors (Day et al., 1992). The combination of such regulation and potentially selective expression of inhibitors and activators for the PCs creates a new level of complexity in producing bioactivities from prohormones.

\section{REFERENCES}

Allen RG, Pellegrino MJ, Peng, B, Pintar JE (1999) Altered POMC processing in SPC2 KO mice. Program Abstr Endocr Soc Annu Meet 270.99.

Berman Y, Mzhavia N, Polonskaia A, Furuta M, Steiner D, Pintar J, Devi L (2000) Defective prodynorphin processing in mice lacking prohormone convertase PC2. J Neurochem 75:1763-1770.

Bunzow JR, Saez C, Mortrud M, Bouvier C, Williams JT, Low M, Grandy DK (1994) Molecular cloning and tissue distribution of a putative member of the rat opioid receptor gene family that is not a $\mu, \delta$, or $\kappa$ opioid receptor type. FEBS Lett 347:284-288.

Day R, Schafer M, Watson SJ, Chretien M, Seidah NG (1992) Distribution and regulation of the prohormone convertases PC1 and PC2 in the rat pituitary. Mol Endocrinol 6:485-497.

Eipper BA, Mains RE (1980) Structure and biosynthesis of pro-adrenocorticotropin/endorphin and related peptides. Endocr Rev 1:1-27.

Eipper BA, Mains RE (1981) Further analysis of post-translational processing of $\beta$-endorphin in rat intermediate pituitary. J Biol Chem 256:5689-5695.

Emeson RB, Eipper BA (1986) Characterization of pro-ACTH/ endorphin-derived peptides in rat hypothalamus. J Neurosci 6:837-849.

Fricker LD, McKinzie AA, Sun J, Curran E, Qian Y, Yan L, Patterson SD, Courchesne PL, Richards B, Levin N, Mzhavia N, Devi LA, Douglass J (2000) Identification and characterization of proSAAS, a granin-like neuroendocrine peptide precursor that inhibits prohormone processing. J Neurosci 20:639-648.

Furuta M, Yano H, Zhou A, Rouille Y, Holst JJ, Carroll R, Ravazzola M, Orci L, Furuta H, Steiner DF (1997) Defective prohormone processing and altered pancreatic islet morphology in mice lacking active SPC2. Proc Natl Acad Sci USA 94:6646-6651.

Hatfield JM, Allen RG, Stack J, Ronnekleiv O (1988) Post-translational processing of pro-opiomelanocortin (POMC)-derived peptides during fetal monkey pituitary development II: $\beta$-endorphins, $\beta$-melanotropins. Dev Biol 126:164-172.

Houtani T, Nishi M, Takeshima H, Sato K, Sakuma S, Kakimoto S, Ueyama T, Noda T, Sugimoto T (2000) Distribution of nociceptin/ orphanin FQ precursor protein and receptor in brain and spinal cord: a study using in situ hybridization and X-Gal histochemistry in receptor-deficient mice. J Comp Neurol 424:489-508.

Jenck F, Moreau J-L, Martin JR, Kilpatrick GJ, Reinscheid RK, Monsma Jr FJ, Nothacker H-P, Civelli O (1997) Orphanin FQ acts as an anxiolytic to attenuate behavioral responses to stress. Proc Natl Acad Sci USA 94:14854-14858

Koster A, Montkowski A, Schulz S, Stube EM, Knaudt K, Jenck F, Moreau JL, Nothacker HP, Civelli O, Reinscheid RK (1999) Targeted 
disruption of the orphanin $\mathrm{FQ} /$ nociceptin gene increases stress susceptibility and impairs stress adaptation in mice. Proc Natl Acad Sci USA 10444-10449.

Lamango NS, Apletalina E, Liu J, Lindberg I (1999) The proteolytic maturation of prohormone convertase 2 (PC2) is a $\mathrm{pH}$-driven process. Arch Biochem Biophys 362:275-282.

Mains RE, Eipper BA (1981) Differences in the post-translational processing of $\beta$-endorphin in rat anterior and intermediate pituitary. $\mathrm{J}$ Biol Chem 256:5683-5688.

Mains RE, Eipper BA, Ling N (1977) Common precursor to corticotropins and endorphins. Proc Natl Acad Sci USA 74:3014-3018.

Marcinkiewicz M, Day R, Seidah NG, Chretien M (1993) Ontogeny of the prohormone convertases PC1 and PC2 in the mouse hypophysis and their colocalization with corticotropin and $\alpha$-melanotropin. Proc Natl Acad Sci USA 90:4922-4926.

Mathis JP, Ross GC, Pellegrino MJ, Jimenez C, Pasternak GW, Allen RG (2001) Carboxyl terminal peptides derived from prepro-orphanin $\mathrm{FQ} /$ nociceptin (ppOFZ/N) are produced in the hypothalamus and possess analgesic bioactivities. Brain Res 895:89-94.

Meunier JC, Mollereau C, Toll L, Suaudeau C, Moisand C, Alvinerie P, Butour J-L, Guillemot J-C, Ferrara P, Monsarrat B, Mazarguil G, Vassart G, Parmentier M, Costentin J (1995) Isolation and structure of the endogenous agonist of opioid receptor-like ORL $\mathrm{O}_{1}$ receptor. Nature 377:532-535.

Pan ZZ, Hirakawa N, Fields HL (2000) A cellular mechanism for the bidirectional pain-modulating actions of orphanin FQ/nociceptin. Neuron 26:515-522.

Quigley DI, McDougall J, Darland T, Zhang GE, Ronnekliev O, Grandy DK, Allen RG (1998) Orphanin FQ is the major OFQ1-17-containing peptide produced in the rodent and monkey hypothalamus. Peptides 19:133-139.
Reinscheid RK, Nothacker H-P, Bourson A, Ardati A, Henningsen RA, Bunzow JR, Grandy DK, Langen H, Monsma FJ, Civelli O (1995) Orphanin FQ: a neuropeptide that activates an opioidlike G proteincoupled receptor. Science 270:792-794.

Rouille Y, Duguay SJ, Lund K, Furuta M, Gong Q, Lipkind G, Oliva Jr AA, Chan SJ, Steiner DF (1995) Proteolytic processing mechanisms in the biosynthesis of neuroendocrine peptides: the subtilisin-like proprotein convertases. Front Neuroendocrinol 16:322-361.

Seidah NG, Chretien M (1992) Proprotein and prohormone convertase of the subtilisin family. Trends Endocrinol Metab 3:133-140.

Sossin WS, Fisher JM, Scheller RH (1989) Cellular and molecular biology of neuropeptide processing and packaging. Neuron 2:1407-1417.

Thorne BA, Thomas G (1990) An in vitro characterization of the cleavage site specificity of the insulin cell prohormone processing enzymes. J Biol Chem 265:8436-8443.

Vaughan CW, Ingram SL, Christie MJ (1997) Actions of the ORL receptor ligand nociceptin on membrane properties of rat periaqueductal gray neurons in vitro. J Neurosci 17:996-1003.

Yu TP, Fein J, Phan T, Evans CJ, Xie CW (1997) Orphanin FQ inhibits synaptic transmission and long-term potentiation in rat hippocampus. Hippocampus 7:88-94.

Zheng M, Streck R, Seidah N, Pintar J (1994) The developmental expression in rat of proteases furin, PC1, PC2, and carboxypeptidase E: implications for early maturation of proteolytic processing capacity. J Neurosci 14:4656-4673.

Zhou A, Mains RE (1994) Endoproteolytic processing of proopiomelanocortin and prohormone convertases 1 and 2 in neuroendocrine cells overexpressing prohormone convertases 1 or 2 . $\mathrm{J}$ Biol Chem 269:17440-17447.

Zhou A, Webb G, Zhu X, Steiner DF (1999) Proteolytic processing in the secretory pathway. J Biol Chem 274:20745-20748. 